\title{
A molecular deletion map of the $Y$ chromosome long arm defining $X$ and autosomal homologous regions and the localisation of the HYA locus to the proximal region of the Yq euchromatin
}

\author{
Amanda J.O'Reilly, Nabeel A.Affara*, Elizabeth Simpson, Phillip Chandler, Els Goulmy and \\ Malcolm A.Ferguson-Smith \\ University of Cambridge, Department of Pathology, Tennis Court Road, Cambridge CB2 1QP, UK
}

Received June 15, 1992; Revised and Accepted July 30, 1992

\begin{abstract}
41 Y-linked DNA probes that detect sequences on the $Y$ chromosome long arm have been used to analyse genomic DNA from a series of 23 patients with deletions of $\mathrm{Yq}$. Southern blot analysis has differentiated 15 distinct breakpoints, which divide $\mathrm{Yq}$ into 14 mapping intervals. From the pattern of DNA sequences present in each patient, it has been possible to produce a congruent deletion map, with the exception of two cases which are not compatible with the consensus order. These patients can be explained by the presence of inversion polymorphisms on $\mathrm{Yq}$ in the general population or by complex rearrangements induced during the formation of the deleted chromosomes. The distribution of sequences on the $Y$ long arm has defined distinct regions of homology with autosomes, the $Y$ short arm and the long and short arms of the $X$. A number of the patients have been typed for the presence or absence of $\mathrm{H}-\mathrm{Y}$ antigen (as determined by the cytotoxic $T$-cell assay) and it has been possible, from anaysis of imformative cases, to assign the locus to the proximal region of the $\mathrm{Yq}$ euchromatin.
\end{abstract}

\section{INTRODUCTION}

The failure of the differential segment of the $Y$ chromosome (which includes the entire long arm) to undergo recombination at meiosis precludes the use of genetic analysis to develop maps of this sex chromosome. Therefore, it has been necessary to rely upon the use of patients with cytogenetically visible abnormalities of the $\mathrm{Y}$ to develop physical deletion maps ${ }^{1-5}$ and to assign genetic functions to sub-regions of the chromosome. Such analysis has indicated that a locus encoding or controlling the expression of the H-Y antigen ${ }^{6}$ and that loci affecting tooth size ${ }^{7,8}$ and spermatogenesis ${ }^{9,10}$ are located in the euchromatic region of the $Y$ long arm.

Of particular value in developing deletion maps of $\mathrm{Yq}$ are individuals who possess a chromosome isodicentric for Yp, where a breakpoint on Yq can be identified. At the cytogenetic level, the differentiation of breakpoints in these cases is limited. However, analysis of genomic DNA from these patients with cloned Yq sequences allows the definition of a number of deletion intervals, thus permitting more precise mapping and genotypephenotype correlations.
In this paper we have used cloned Yq DNA sequences (isolated from $Y$ chromosome-specific libraries) to analyse DNA from patients with structural abnormalities affecting the $Y$ long arm. This analysis has differentiated 15 breakpoints amongst 23 patients and has permitted the assignment of $\mathrm{Yq}$ sequences to 14 mapping intervals. $\mathrm{H}-\mathrm{Y}$ antigen typing of a number of these patients has allowed the assignment of the HYA locus to a region covering the proximal segment of the Yq euchromatin. Further, the patterns of homology of these sequences to other chromosomes has allowed further elucidation of the organisational structure of the euchromatic region of $\mathrm{Yq}$.

\section{RESULTS}

\section{Isolation of $\mathrm{Yq}$ DNA sequences}

Single-copy DNA sequences (isolated from either a flow-sorted chromosome $\mathrm{Y}$-specific library or $\mathrm{Y}$ cosmids derived from a $\mathrm{Y}$ only cell hybrid library) which map to $Y q$ were identified by hybridization to the panel illustrated in figure 1 . The key members of this panel are the Y-only somatic cell hybrid 7631, ED (a patient with two $\mathrm{X}$ chromosomes and two dicentric iso $\mathrm{Yq}$ chromosomes with a breakpoint in $\mathrm{Yp}$ at $\mathrm{Yp} 11.2)$ and WC (a patient with a single $\mathrm{X}$ chromosome and a monocentric iso $\mathrm{Yp}$ chromosome generated by centric fusion). Sequences from the $\mathrm{Y}$ were identified by hybridization to $\mathrm{Y}$-only hybrid DNA, those located on proximal Yp by hybridization to both WC and ED DNA, those located on distal Yp by hybridization to WC (and not ED) DNA and those located on Yq by hybridization to ED but not WC DNA. Any $X$ homologies were indicated by hybridization to the DNA of the X-only somatic cell hybrid Horl $X$. Several of the probes detect homologies in other regions of the $\mathrm{Y}$, some on the $\mathrm{X}$ and others on autosomes.

Analysis of patients with $\mathrm{Y}$ long arm breakpoints using Yq DNA sequences

The ideograms in figure 2 present a schematic summary of the aberrant $Y$ chromosomes revealed by cytogenetic analysis of our panel of patients. Two categories of dicentric iso Yp chromosome have been distinguished amongst these patients with breakpoints (based on the banding pattern of the $\mathrm{Y}$ described by Magenis ${ }^{18}$ ) in $\mathrm{Yq} 11.21$ and $\mathrm{Yq} 11.22$. In addition, a patient with the derivative 

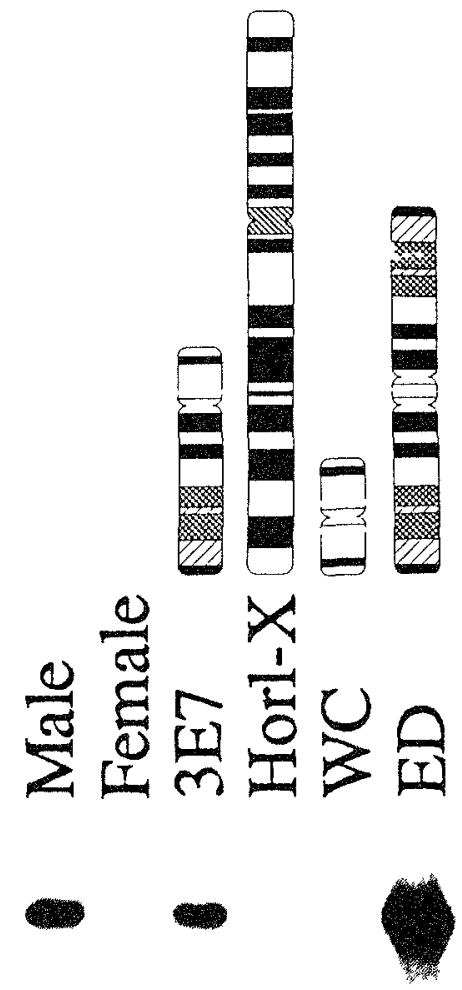

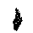

Figure 1 Mapping panel for the rapid regional assignment of $Y$ probes Hybridization of probes to this panel allowed therr localization to the long or short arm of the $\mathrm{Y}$ chromosome and identıfied any $\mathrm{X}$ or autosomal homologies The figure shows the hybridization of the probe GMGY21 which maps to the long arm of the $Y$ ED has two isodicentric Yq chromosomes with a breakpoint at Yp11 1 WC has a monocentric isoYp chromosome 3E7 and Horl $X$ are $Y$ only and $X$ only somatic cell hybrids on a mouse background

5 from a $5 \mathrm{Y}$ translocation, a patient with the derivative 14 of a $14 \mathrm{Y}$ translocation, a patient with a ring $\mathrm{Y}$, a patient with a Yq deletion with a breakpoint at Yq 1123 and three patients with the derivative $X$ from $X$ Y translocations have contributed to the collection of Yq breakpoints In all, the panel consists of 23 patients The data from the analysis of this panel with the full set of Yq DNA sequences is summarised in table 1 The $\mathrm{Yq}$ sequence scored by probe $50 \mathrm{f} 2$ is the $\mathrm{E}$ fragment

From the profile of DNA sequences in these patients it is possible to construct a linear series of breakpoints delineating 14 mapping intervals labelled YQ1-YQ14 This is shown in
Table 1 The pattern of Yq sequences present in members of the deletion pancl W A D K M D J C F F C I K R

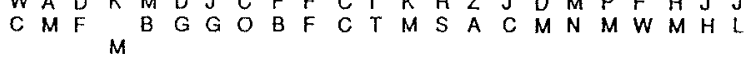

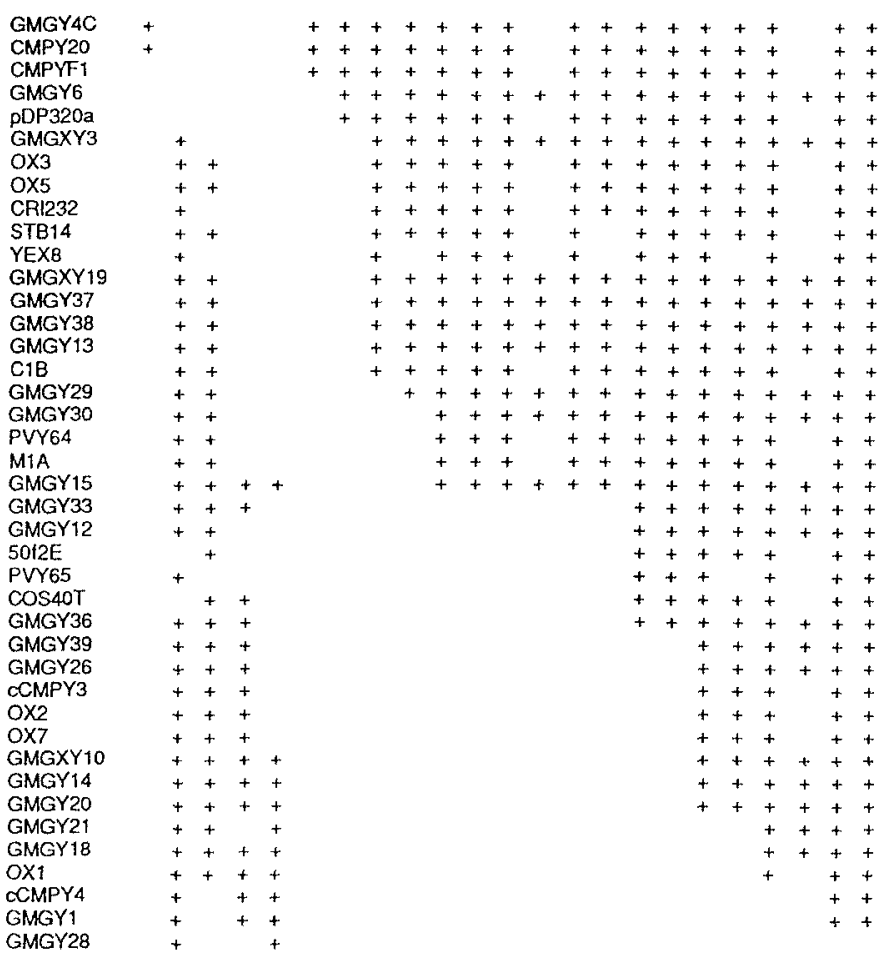

(+) indicates the piesence of a Yq signal and ( ) indicates the absence of a Yq signal () indicates not determined

figure 3 Two patients (DF and K M) do not fit into this map, both have distal Yq sequences in the absence of those located in a more proximal position These data expand and revise the previously publıshed ${ }^{3}$ analysis of Yq breakpoints, altering the intervals defined in that study

In addition to detecting $Y$ specific DNA fragments, several of these probes also have $\mathrm{X}$ or dutosomal homologies and some detect sequences which map to other regions of the $Y$ chromosome Thes datd are summarised in table 2 Some of these homologies are apparent at low stringency only, while others are retained at high stringency washing conditions

\section{Localisation of the HYA locus using the Yq panel}

Expression of the $\mathrm{H} Y$ antigen, a minor histocompatibulity antigen which causes rejection of male to female grafts within inbred strains of mice, has been mapped in humans previously to the $Y$ chromosome long arm or centromeric region ${ }^{6}$ In an attempt to delineate this interval more precisely, H Y antigen status, using the cytotoxic $T$ cell assay ${ }^{6}$, was determined for informative members of the deletion pancl The data for patients WC, JC, DM and FW are summarised in table 3 It was not possible to type all individuals because of MHC restrictions of the $\mathrm{H}-\mathrm{Y}$ specific $T$ cell clones dvallable Analysis of the informative cases indicates that the region of the $\mathrm{Y}$ responsible for $\mathrm{H} Y$ antigen expression corresponds to the intervals between CEN and YQ8 as indicated in figure 3 From the cytogenetic analysis of these patients this places the locus in Ycen Yq11 21 


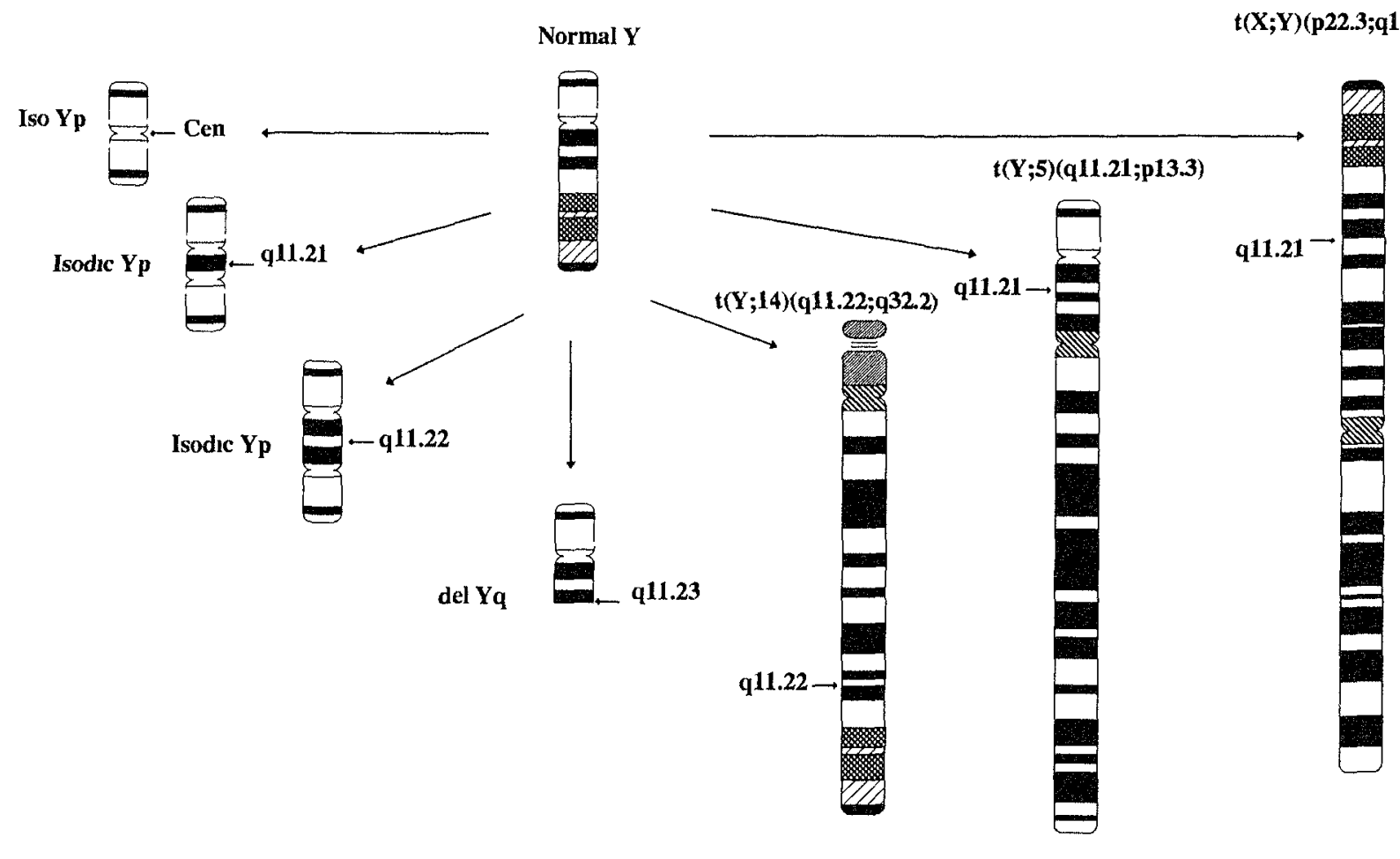

Figure 2. The figure summarises the categones of $Y$ abnormalities found amongst the patients of the deletion panel DG (ring Y) is not illustrated

\section{DISCUSSION}

Molecular analysis of these patients with probes that detect sequences on $\mathrm{Yq}$ has revealed the existence of 15 breakpoints and made possible the construction of a Yq deletion map in which Yq probes have been assigned to 14 intervals In so doing, the precision of karyotype-phenotype correlations in patients with $Y$ abnormalitıes will be improved and further enhanced as simulat Yq maps assembled by others ${ }^{4-22}$ are integrated into a unitary description of $\mathrm{Yq}$

Through mutual typing of patients $\mathrm{CO}, \mathrm{FF}, \mathrm{RS}, \mathrm{JC}$ and DM we have been able to cross-reference to a limited extent our $\mathrm{Yq}$ intervals to the deletion map of David Page's laboratory (Douglas Vollrath, personal communication and manuscript in preparation), and, consequently to the original map of the $\mathrm{Y}$ produced by Vergnaud et al ${ }^{4}$ The Vergnaud map intervals describing Yq are shown aligned against our own intervals in figure 3 Patients $\mathrm{CO}, \mathrm{FF}$ and RS have breakpoints in interval 5 of the Vergnaud map, and patients JC and DM in interval 6 Thus the boundary between intervals 5 and 6 of the Vergnaud map occurs between patients JC and DM on the Aistal side, and patients FF and RS on the proximal side Interval $4 \mathrm{~B}$ defines the centromere and interval 7 marks the start of the distal heterochromatic repeats From this, it is possible to assign our intervals YQ1-YQ6 as sub-divisions of the Vergnaud interval 5 and the distal segment of YQ8 to interval \Q14 as sub-divisions of interval 6 since patients $\mathrm{JH}$ and $\mathrm{JL}$ do not contain any of the heterochromatic repeats of distal Yq (corresponding to interval 7) At this point we cannot assign interval YQ7 to interval 5 or 6 and similarly, for the proximal part of interval YQ8 The order of breakpoints defined by the two maps for the patients typed in common using
Table 2. Summary of homologies detected by Yq probes

\begin{tabular}{|c|c|c|c|c|c|c|c|c|c|}
\hline \multicolumn{2}{|c|}{ No Homologles } & \multicolumn{2}{|l|}{ YqX } & \multicolumn{2}{|c|}{ Yq Autosomal } & \multicolumn{2}{|c|}{ Yq Autosomai/X } & \multicolumn{2}{|l|}{$Y q-Y p$} \\
\hline GMGYG & (2) & PDP320A & (2) & GMGY4C & (cen) & CMPY2O & $(\operatorname{cen} / / p)$ & & (8) \\
\hline YEXB & (3) & GMGXY3 & (3) & $0 \times 3$ & (3) & GMGY37 & (3) & GMGY39 & (10) \\
\hline GMGY13 & (3) & $0 \times 5$ & (3) & OX5 & (3) & GMGY38 & (3) & GMGY26 & (10) \\
\hline GMGY 30 & (5) & cri232 & (3) & $\mathrm{C} 1 \mathrm{~B}$ & (3) & PVY64 & (5) & СCMPY3 & (10) \\
\hline GMGY15 & (6) & STS & (3) & $50+2$ & (8) & GMGY12 & (8) & $0 \times 2$ & (10) \\
\hline GMGY 33 & (7) & GMGXY19 & (3) & $0 \times 2$ & (10) & PVY65 & (8) & $O \times 7$ & (10) \\
\hline $\operatorname{Cos} 40 \mathrm{~T}$ & (9) & $\mathrm{mta}$ & (5) & $0 \times 7$ & (10) & GMGY39 & (10) & GMGXY1O & b(11) \\
\hline \multirow[t]{9}{*}{ GMGY36 } & (9) & GMGXY 10 & (11) & CCMPY 4 & (13) & CCMPY3 & (10) & GMGY14 & (11) \\
\hline & & & & GMGY2B & (14) & & & OX1 & (12) \\
\hline & & & & CMPY21 & (12) & & & & \\
\hline & & & & GMGY29 & (4) & & & & \\
\hline & & & & GMGY26 & (10) & & & & \\
\hline & & & & GMGY21 & (12) & & & & \\
\hline & & & & GMGY1 & (13) & & & & \\
\hline & & & & GMGY20 & (11) & & & & \\
\hline & & & & GMGY18 & (12) & & & & \\
\hline
\end{tabular}

The numbers in brackets refer to Yq deletion intervals YQ1-YQ14 The category $\mathrm{Yq}$ autosomal/X contans probes whose homologies have not yet been assigned to autosomes or the $\mathrm{X}$ chromosome

a completely non-overlapping set of markers is identical, except that we have been able to resolve patients DM and JC as separate breakpoints

The development of a molecular deletion map of $Y \mathrm{p}$ has been achieved in a similar way by studying $X-Y$ interchange in $X X$ male patients ${ }^{12}$ Here too, apparent exceptions to the consensus order (as with patients $\mathrm{K}-\mathrm{M}$ and $\mathrm{DF}$ for the $\mathrm{Yq}$ map) were discovered and could reflect inversion polymorphisms of the $Y$ in the general population or rearrangements induced during the formation of these aberrant $Y$ chromosomes In this context, Donlon and Muller $^{23}$ have provided evidence of $\mathrm{Yq}$ sequences 


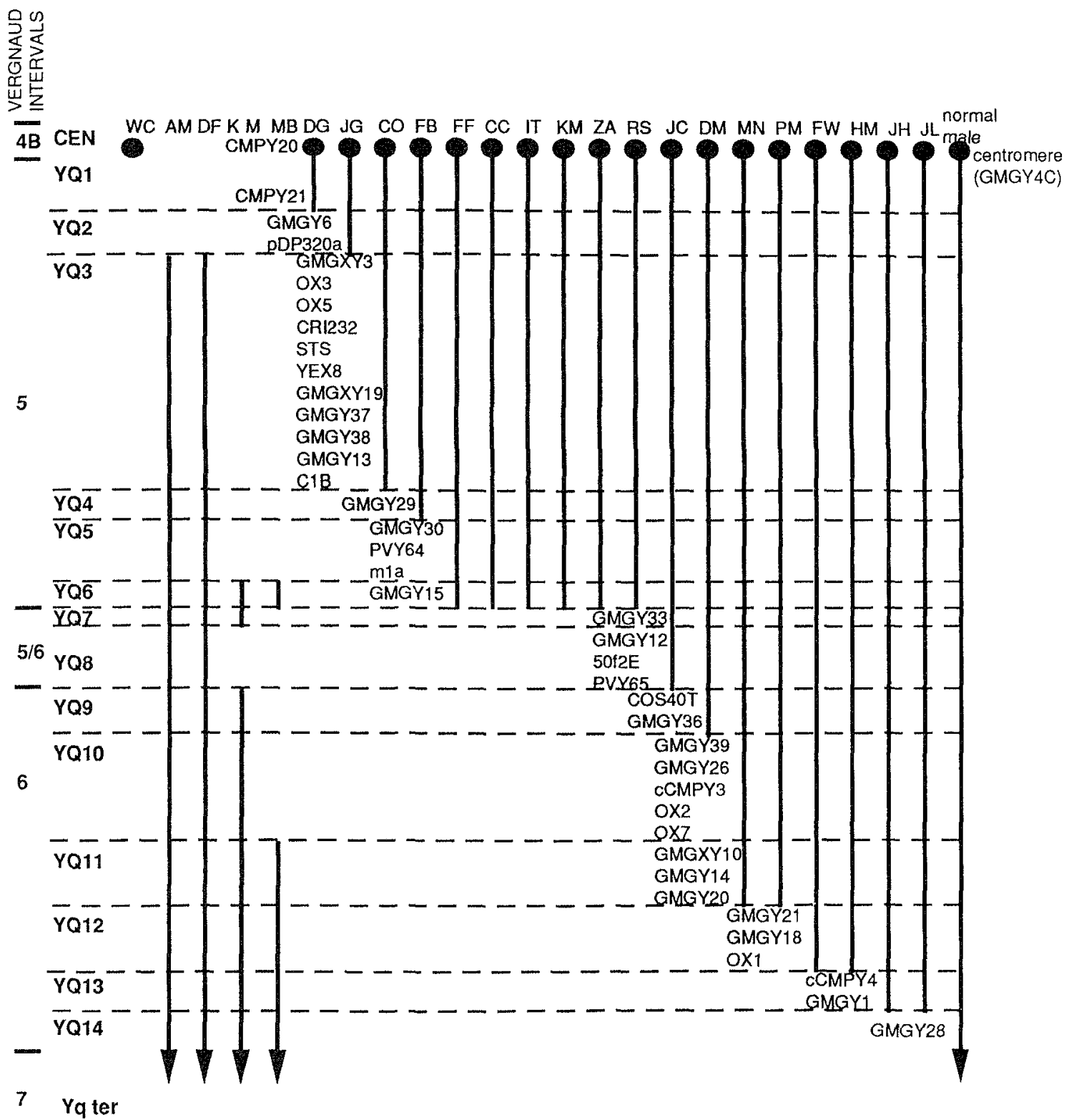

Figure 3 The figure shows a schematic deletion map of Yq derived from the data shown in table 1 and illustrates the position of probes in relation to bredkpoints The deletion intervals are numbered YQ1-YQ14 and are shown aligned against the deletion intervals of the map of Vergnaud ${ }^{4}$

in XX males which they suggest could be generated by pericentric inversion in the paternal $Y$ chromosome

As mentioned above, the establishment of a deletion map of the $Y$ long arm makes it possible to produce more precise correlations between the various mapping intervals defined by patients and any clinical phenotype caused by deletions in the euchromatic regions of $\mathrm{Yq}$ Deletions involving the euchromatic segment of $\mathrm{Yq}$ have suggested that genes important in spermatogenesis and tooth size map to Yq11 In mouse, the Hya locus and Spy, a locus controlling spermatogenesis, have been found to be closely linked ${ }^{24}$ Linkage between HYA and AZF in man is also evident ${ }^{622}$, our patients WC (also analysed in the paper by Simpson et al ${ }^{6}$ ), JC, DM and FW localise HYA to Ycen-Yq11 21 On the basis of azoospermic patients deleted for Yq11, this region seems also to be necessary for successful spermatogenesis in humans Great care, however, has to be exercised in interpreting such correlations in order to exclude mosaicism or perturbation of $\mathrm{X}-\mathrm{Y}$ pairing during meiosis provoked by the abnormal structure of dicentric 1so $Y p$ chromosomes as the cause of infertility Consequently, conclusions of the clinical significance of the euchromatic region of $\mathrm{Yq}$ founded on karyotype-phenotype correlations must be based on Yq-chromosomes where mosacism can be excluded

The ambiguities introduced by mosaicism into the interpretation of other cell lines typed as negative for $\mathrm{H}-\mathrm{Y}$ antıgen has prevented us from defining a more precise mapping interval for the HYA locus Nevertheless, the location we have defined for the HYA locus agrees well with that determined by Cantrell et al ${ }^{25}$ Their case 5 is positive for $\mathrm{H}-\mathrm{Y}$ antigen and the probe $50 \mathrm{f} 2 \mathrm{E}$ and has a breakpoint in interval 6 of the map of Vergnaud et al ${ }^{4}$ This 
Table 3. Summary of H-Y Antigen Typing

\begin{tabular}{|c|c|c|c|c|c|c|c|}
\hline & \multicolumn{2}{|c|}{ HLA Serotype } & \multicolumn{4}{|c|}{$\%$ lysis with cytotoxic cells specitic for } & \multirow[t]{2}{*}{$H-Y$ type } \\
\hline & & & & & & $B 7 / H-Y$ & \\
\hline \multicolumn{8}{|l|}{ Exp.1 } \\
\hline Control Male & 2 & $7^{\mathrm{a}, 62}$ & NDb & ND & $37^{\circ}$ & 80 & + \\
\hline Control Female & 3 & $\frac{1}{2}$ & ND & ND & 47 & 1 & . \\
\hline DM & 1,2 & $\bar{z}$ & ND & ND & 52 & 72 & + \\
\hline \multicolumn{8}{|l|}{ Exp.2 } \\
\hline Control Male & 3 & $Z, 13$ & ND & ND & 60 & 87 & + \\
\hline Control Female & 3,24 & $\bar{z}$ & ND & ND & 41 & 6 & - \\
\hline JC & 3 & $\underline{z}$ & ND & ND & $\overrightarrow{56}$ & 72 & + \\
\hline \multicolumn{8}{|l|}{ Exp. 3} \\
\hline Control Male & 1,2 & 7,8 & 64 & 29 & ND & ND & + \\
\hline Control Female & 2,3 & 15 & 62 & 0 & ND & ND & : \\
\hline FW & 12 & $? 15$ & 52 & 25 & NO & NO & + \\
\hline wC & 2 & 12 & 85 & 0 & NO & ND & \\
\hline
\end{tabular}

Pror to $\mathrm{H}-\mathrm{Y}$ antigen typing, HLA typing was done to determine whether the pattents were of $\mathrm{A} 2$ or $\mathrm{B} 7$ types, since the T-cell clones avalable for $\mathrm{H}-\mathrm{Y}$ typing were restricted by ether HLA-A2 or HLA-B7 Standard HLA serotyping was performed at the tissue typing laboratory at the Royal Postgraduate Medical School (Hammersmith, London) by Mr Nick Davey and by fluoresence-activated cell sorting (FACS) analysis at the Clinical Research Centre (Harrow, UK) using the HLA-A2 specific monoclonal antibody HB82 (BB7 2) and the HLA B7 (crossreactive on B40) monoclonal antibody HB59 (MB40 2) Expression of HLA $\mathrm{A} 2$ and $\mathrm{B} 7$ alloantugens identufied by $\mathrm{T}$ cells was confirmed by cytotoxic $\mathrm{T}$-cell lysis (CTL) experiments in which the patients' cells were also typed for $\mathrm{H}-\mathrm{Y}^{6}$ Epstem-Barr virus-transformed lines from each of the patient were used as target cells in CTL assays. The cytotoxicity was measured in a ${ }^{5 I} \mathrm{CR}$ release assay as described previously ${ }^{6}$ Control normal male and temale cell lines were examined with each experiment

a The identity of the HLA restriction molecule used as a restriction element for the detection of H-Y antigen in the CTL assays is underluned in the HLA serotyping columns

${ }^{\mathrm{b}} \mathrm{ND}=$ not done

${ }^{c}$ Figures underluned in the CTL test columns are those showing significant levels of titrating lysis

is very similar to the distal limit defined by our patient JC who is also positive for $50 \mathrm{f} 2 \mathrm{E}$ and the $\mathrm{H}-\mathrm{Y}$ antigen, where the breakpoint (by cross-referencing to the common patients typed by ourselves and Douglas Vollrath - see figure 3 ) has been shown to lie in interval 6. Case 4 of the Cantrell et al. ${ }^{25}$ study is $\mathrm{H}-\mathrm{Y}$ antigen negative and has a breakpoint between the centromere and interval 6, probably in interval 5 of the Vergnaud map.

At least five categories of sequences mapping to $\mathrm{Yq}$ can be distinguished and the establishment of a deletion map has been useful in indicating how these are organised. Figure 4 summarises the arrangement of these sequences on $\mathrm{Yq}$ as it is presently understood; (1) sequences which are specific to the $\mathrm{Y}$ chromosome, (2) sequences which define a block of homology with Xp22.3-pter, (3) sequences which detect homologies with $\mathrm{Xq} 28$, (4) sequences which define a block of homology with $Y p$ and (5) sequences which detect homologies with autosomes. For several sequences it has not yet been determined whether the homologies are to the $X$ or autosomes.

The block of X-Y homology in proximal $\mathrm{Yq}$ (homologous to Xp22.3-pter) contains the STS pseudogene (STSP) and several other closely linked sequences ${ }^{26}$. It is believed to have arisen on $\mathrm{Yq}$ as a result of a pericentric inversion in an ancestral $\mathrm{Y}$ chromosome leading to the removal of this group of sequences from the $X-Y$ pairing region ${ }^{27}$. This is supported by the finding that the probe m1a maps to interval YQ5, which is distal to the YQ3 interval containing GMGXY3, STS, GMGXY19 and CRI232. On the short arm of the $X$ there is a similar arrangment which if inverted on the ancestral $Y$ would give rise to the order shown in figure 3 . The same findings have been observed by
Number of probes in each interval for each category of homology

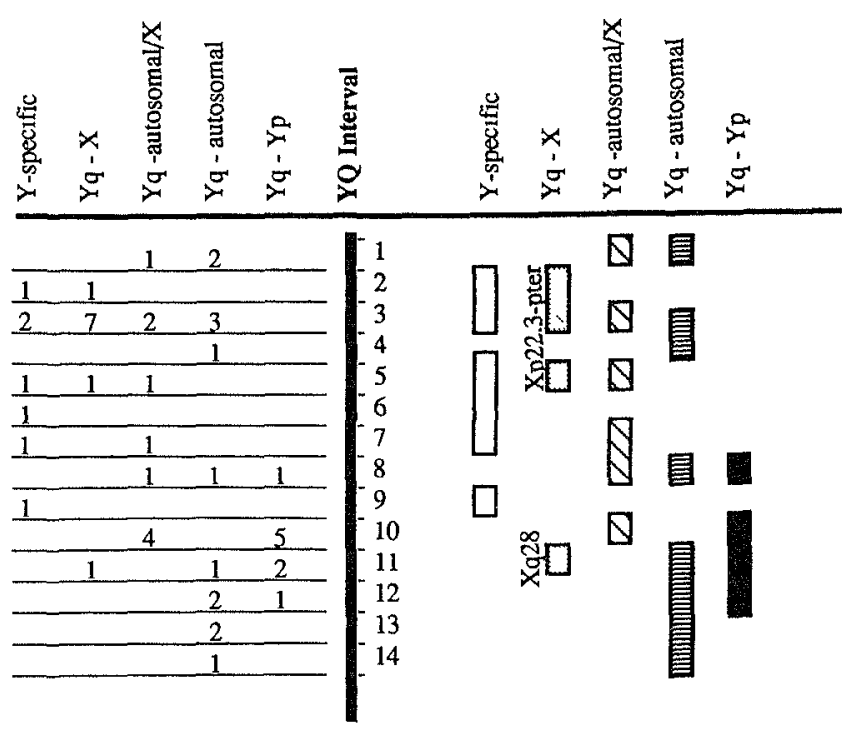

Figure 4. The figure displays schematically the arrangement of the sequences in $Y q$ that detect $X$, autosomal and $Y p$ homologies, and also sequences that are $Y$ specific

Bardoni et al. ${ }^{20}$. Thus these sequences probably represent ancient homologies which date from the ancestral homologues which gave rise to the sex chromosomes.

In contrast, the Yq-Xq28 homology is of more recent origin and includes not only the sequence GMGXY10 but also the sequences DXYS61 and DXYS64 $4^{28,29}$. Bardoni et al. ${ }^{20}$ have shown that DXYS61 and DXYS64 map to the Yq telomere whereas the GMGXY10 locus is located in the distal Yq euchromatin. DXYS61 and DXYS64 sequences are of more recent origin, appearing on the $Y$ between chimpanzee and human, whereas GMGXYIO is older and is likely to have moved to the $\mathrm{Y}$ before the divergence of the old world monkeys ${ }^{30}$. Duplicative transposition from the $\mathrm{X}$ is the most likely explanation for the appearance of these sequences on the $Y^{31}$.

The presence of Yq-Yp homologies suggests the occurrence of duplications and intrachromosomal rearrangements (either inversions or transpositions or both) during the evolution of the $Y$. In this respect, several of the sequences which detect multiple loci may reflect expansion of blocks of sequence by such mechanisms.

Many of the sequences mapping to $\mathrm{Yq}$ with autosomal homologies may have colonised the $\mathrm{Y}$ by transposition or retroposition, the latter resulting in the deposition of processed pseudogenes. There are a number of examples of $Y$ pseudogenes which include actin $^{32}$, argininosuccinate synthetase ${ }^{33}$, two anonymous transcripts described by Leroy et al. ${ }^{34}$ and GMGY28 which represents a processed pseudogene derived from a chromosmome 2 transcript (unpublished results). The generation of intrachromosomal rearrangements and the importation of sequences from other chromosomes may be important events in initiating and preserving a sex determining role for the $\mathrm{Y}$ by preventing pairing and recombination of the differential portion with the $\mathrm{X}$. 


\section{MATERIALS AND METHODS}

\section{Chromosome specific librarres and cell lines}

The chromosome specific libraries and cell Ines WC $(46, X$ with a monocentric 1so Yp chromosome), ED (48, XX with two dicentric iso Yq chromosomes, AMIR2N ( $\mathrm{d}$ somatic cell hybrid containing the derivative $X$ chromosome of the following translocation $t(X, Y)(p 223, q 111))$, the $Y$ only somatic cell hybrid 7631 and the $X$ only somatic cell hybrid Horl $X$ have all been described in detall elsewhere ${ }^{1311} 12$ Single copy DNA sequences were isolated from chromosome specific libraries

\section{Patient material}

Patient $W C$ has a monocentric rso $Y p$ chromosome Patients JC, CO, FF, CC, IT, KM, ZA, RS, DM and FB have dicentric iso Yp chromosomes with a breakpoint in Yq11 21 Patients MN, PM, FW, HM and JH all possess dicentric iso Yp chromosomes with a breakpont in Yq11 22 (see figure 2) Patients AM (from which the hybrid AMIR2N is derived), DF and $K M$ possess the derivative $X$ of $X Y$ translocations $(t(X, Y)(p 223, q 1121))$ and patsents $J G$ and $M B$ the respective denvatives of a $Y 5(t(Y, 5)(q 1121, p 133))$ and a $Y 14(t(Y, 14)$ (q11 22,q32 2) translocations Patient DG has a ring $Y(46, \mathrm{XrY})$ and patient JL is 46,XYq-with loss of the distal heterochromatic region from Yq11 23 Patients $\mathrm{JC}, \mathrm{CO}, \mathrm{CC}, \mathrm{RS}, \mathrm{MN}, \mathrm{JG}$, and JL were obtaned from Ellen Magenıs $\mathrm{K} \mathrm{M}$ was obtaned from Nick Dennıs FB was obtamed from John Pearson MB was obtained from Diane Curtas

\section{Preparation of genomic DNA and Southern blot analysis}

Preparation of high molecular weight genomic DNA from peripheral blood lymphocytes or lymphoblastold cell lines, restriction digests and Southern transfers were carried out as described by Maniatis et al ${ }^{13}$ DNA probes were labelled by oligonucleotide random priming as described by Fernberg and Vogelstein ${ }^{14}$ and molecular hybridization under the conditions described by Wahl et al 15

\section{Determination of H-Y status}

Lymphoblastord cell lines were typed for $\mathrm{H}-\mathrm{Y}$ antigen using the cytotoxıc $\mathrm{T}$ cell assay described by Simpson et al ${ }^{6}$

\section{DNA probes}

The probe pDP320a (DYS148) was provided by David Page and has been described by Fisher et al ${ }^{16}$ Probes YEX8, PVY64 and PVY65 were obtamed from Peter Vogt Probes OX1 (DYS27), OX2 (DYS26), OX3 (DYS28), OX5 (DYS30) and OX7 (DYS33) were obtaned from Ian Crasg Probe CRI 232 (DXS278) was obtaned from Collaboratıve Research The steroid sulphatase (STS) probe was obtaned from Andreds Ballabio Probe M1A (DXS31) was obtanned from J L Mandel Probe 5012 (DYS7) was obtained from Jean Weissenbach Probe $\mathrm{ClB}$ is a cosmid fragment obtaned from Kay Taylor Probe cos40T is a cosmid fragment obtained from Chrs Lau Probes Y46 I (cCMPY4) and 14 1/1B (cCMPY3) are cosmud fragments obtaned from Carole Sargent Probes GMGYI (DYS12), GMGY6 (DYS66), GMGY4C (DYS52), GMGY12 (DYS64) GMGY13 (DYS63), GMGY14 (DYS118), GMGY15 (DYS62), GMGY18 (DYS75), GMGY20 (DYS73), GMGY21 (DYS72), GMGY26 (DYS77), GMGY28 (DYS79), GMGY29 (DYS80), GMGY30 (DYS84), GMGY33, GMGY36 (DYS88), GMGY38 (DYS86), GMGY39 (DYS89), GMGXY3 (DXYS29Y), GMGXY19 (DYS74), GMGXY10 (DXYS37Y), and CMPY21 were 1solated from a flow-sorted Y lambda library ${ }^{17}$ Probe 691 \#10 (CMPY20) was isolated from a foetal brain cDNA library (Stratagene 937201)

\section{ACKNOWLEDGEMENTS}

We would like to thank Marıon Perryman and Marie Ferguson Smith for dssistance in the culture of lymphoblastord cell lines We would like to thank Ellen Magenıs, Nick Dennis, John Pearson and Diane Curtis for Yq deletion patients This work was supported by grants from the Medical Research Council A OR is a Wellcome Trust Prize Student

\section{REFERENCES}

1 Affara, N A, Florentm, L, Morrison, N, Kwok, K, Mutchell, M , Cooke, A , Jamieson, D , Glasgow, L , Meridth, L, Boyd, E and Ferguson-Smuth, M A (1986d) Regional assignment of $Y$ linked probes by deletion mapping and their homology with $X$ chromosome and autosomal sequences Nuc Acids Res $145353-5373$

2 Affara, N A, Ferguson Smith, M A Tolme, J, Kwok, K, Mitchell M, Jamieson, D, Cooke, A and Florentın, L (1986b) Variable transfer of Y-specific sequences in XX males Nuc Acids Res $145375-5387$
3 Ferguson Smith, M A , Affara, N A and Magents, R E (1987) Orderng of $Y$ specific sequences by deletion mapping and analysis of $X-Y$ interchange males and females Development 101 (supp) $41-50$

4 Vergnaud, G , Page, D C Simmler, M C , Brown, L , Rouyer, F, Noel, B , Botstein, D , de la Chapelle, A and Weissenbach, J (1986) A Deletion Map of the Human Y Chromosome Based on DNA Hybridication Am $J$ Hum Gen 38 109-124

5 Page, D C (1986) Sex reversal deletion mapping the male determining function of the Y chromosome Cold Spring Har Symp Quan Biol 51 $229-135$

6 Simpson, E, Chandier, P, Goulmy, E, Disteche, C M , Ferguson-Smith, $\mathrm{M} \mathrm{A}$ and Page, D C (1987) Separation of the genetic loci for the H-Y antigen and for testis determmation human $\mathrm{Y}$ chromosome Nature $326876-878$

7 Alvesalo,L, Osborne, R H and Karı, M (1975) The 47, XYY Male, Y Chromosome, and Tooth Size Am J Hum Genet 27 53-61

8 Alvesalo, $L$ and de le Chapelle, A (1981) Tooth sizes in two males with deletions of the long arm of the $\mathrm{Y}$ chromosome Ann Hum Genet 45 $49-54$

9 Tiepolo, L and Zuffard, O (1976) Localization of Factors Controlling Spermatogenesis in the Nonfluorescent Portion of the Human Y Chromosome Long Arm Hum Genet 34 119-12 12

10 Andersson, M, Page, D C , Pettay, D , Subrt, I, Turleau, C, de Grouchy,J and de la Chapelle, A (1988) Y, autosome translocatıons and mosarcism In the aetiology of $45, X$ maleness assignment of a fertility factor to distal Yq11 Hum Genet 79 2-7

11 Goodfellow, P , Banting, G , Sheer, D, Ropers, H H , Cdine, A, Ferguson Smith, M A, Povey, S and Voss, R (1983) Genetic evidence that a Y Inked gene in man is homologous to a gene on the $X$ chromosome Nature $302 \quad 346-349$

12 Affard, N A, Ferguson Smith, M A, Magens, R E , Tolme, J L, Boyd, E, Cooke, A, Jamieson, D, Kwok, K, Mitchell, M and Snadden, L (1987) Mapping the testis determinants by an analysis of $Y$-specific sequences in males with dpparent $\mathrm{XX}$ and $\mathrm{XO}$ karyotypes and females with $\mathrm{XO}$ karyotypes Nuc Acids Res $157325-7342$

13 Manatis, T ,Fritsch, E F and Sambrook, J (1982) Molecular Clonng, a laboratory manual (Cold Spring Harbour, New York Cold Spring Harbour Laboratory)

14 Feinberg, A P and Vogelstein, B (1983) A Technique of Radiolabellıng DNA Restriction Endonuclease Fragments to High Specific Activity Analyt Biochem 132 6-13

15 Wahl, G M , Stern, M and Stark, G R (1979) Efficient transfer of large DNA fragments from agarose gels to diazobenzyloxymethyl-paper and rapid hybridization by using dextran sulphate Proc Natl Acad Sei U S A 76 $3683-3687$

16 Fisher, E M C Altalo, T, Luoh, S, de la Chapelle, A and Page, D C (1990) Human Sex Chromosome Specific Repeats Within a Region of Pseudodutosomal $/ \mathrm{Yq}$ Homology Genomics $7 \quad 625-628$

17 Mitchell, M (1989) PhD Thesis, University of Glasgow

18 Magems, R E, Tochen, M L, Holohan, K P , Carey, T, Allen, T and Brown, M G (1984) Turner syndrome resultung from partidl deletion of $Y$ chromosome short arm Localization of male determinants J Pediatrics 105 916-919

19 Nakahorı, Y, Tamurd, T, Nagafuchı, S, Fulıede, K, Minowda, S, Fukutan, K, Fuse, H , Hayashı, K , Kurokı, Y ,Fukushıma, Y, Agematsu, $K$, Kuno, $T$, Kaneko, S, Yamada, K, Kitagawa, $T$, Nonomura, $M$, Fukuda, S , Kusano, M, Onıgata, S , Hıbı, I and Nakagome, Y (1991) Molecular Cloning and Mapping of 10 New Probes on the Human Y Chromosome Genomics 9 765-769

20 Bardonı, B, Zuffardı, O , Guolo, S, Ballabı, A, Simı, P, Cavallı, P Grımold, M G, Fraccaro, M and Camerıno, G (1991) A Deletion Map of the Human Yq11 Region Implications for the Evolution of the $Y$ Chromosome and Tentative Mapping of a Locus Involved in Spermatogenesis Genomics 11 443-451

21 Oosthuizen, C J J , Herbert, J S, Vermaak, L K , Brusnicky, J Frıcke, $\mathrm{J}$, du Pleiss, $\mathrm{L}$ and Retief, A E (1990) Deletion mapping of isoldted $Y$ chromosome DNA tragments Hum Genet 85 205-210

22 Ma, K, Shharkey, A, Kursch, S, Vogt, P, Kell, R, Hargredve, T B, McBedth S and Chandley, A C (1992) Towards the molecular localisation of the AZF locus mapping of microdeletions in azoospermic men within 14 subintervals of interval 6 of the human $Y$ chromosome Hum Mol Gen 1 29-33

23 Donlon, T A and Muller, U (1991) Deletion Mappung of DNA Segments from the $Y$ Chromosome Long Arm and Their Analysis in an XX Male Genomics $1051-56$ 
24 Burgoyne, P S, Levy, E R and McLaren, A (1986) Spermatogenic falure in mice lackıng $\mathrm{H} Y$ antigen Nature $320 \quad 170-172$

25 Cantrell, M A, Bogan, J S , Simpson, E, Bıcknell, J N , Goulmy, E, Chandler, P, Pagon, R A , Walker, D C , Thulıne, H C , Graham, J M , de la Chapelle, A , Page, D C and Disteche, C M (1992) Deletion Mapping of H-Y Antigen to the Long Arm of the Human Y Chromosome Genomics, in press

26 Newman, R S , Affara, N A, Yates, J R W , Mitchell, M and Ferguson Smith, M A (1990) Physical mapping of deletion breakpoints in patients with $\mathrm{X}$ linked ichthyosis evidence for clusterng of distal and proximal breakpoints Proc R Soc London B 242 231-239

27 Yen, P H , Marsh, S, Allen, E, Tsai, S P, Ellison, J, Connoly, L, Neıswanger, K and Sapıro, L J (1988) The Human X-Lınked Sterold Sulphatase Gene and a Y-Encoded Pseudogene Evidence for an inversion of the Y Chromosome during Primate Evolution Cell 55 1123-1135

28 Bickmore, W A and Cooke, $\mathrm{H} \mathrm{J} \mathrm{(1987)} \mathrm{Evolution} \mathrm{of} \mathrm{homologous} \mathrm{sequences}$ on the human $\mathrm{X}$ and $\mathrm{Y}$ chromosomes, outside of the metotic pairmg segment Nuc Acids Res $156261-6271$

29 Arveler, B, Vincent, A and Mandel, J L (1989) Towards a Physical Map of the Xq28 Region in Man Linking Colour Vision, G6PD, and Coagulation Factor VIII Genes to an X-Y Homology Region Genomics 4 $460-471$

30 Lambson, B , Affara, N A , Mitchell, M, Ferguson Smith, M A (1992) Evolution of DNA Sequence Homologies Between the Sex Chromosomes in Primate Species Genomics, in press

31 Page, D C, Martinville, B , Barker, D, Wyman, A, White, R, Francke, $\mathrm{U}$ and Botstem, $\mathrm{P}$ (1982) Single copy sequence hybridises to polymorphic and homologous loci on the human $\mathrm{X}$ and $\mathrm{Y}$ chromosomes Proc Natl Acad Sci U S A $795352-5356$

32 Heilı, R, Hanauer, A , Grzeschık, K H and Hors-Cayla, M C (1984) Actun-like sequences are present on human $\mathrm{X}$ and $\mathrm{Y}$ chromosomes Embo J $3 \quad 1803-1807$

33 Daiger, S P Wildın, R S and Su, T S (1982) Sequences on the human $\mathrm{Y}$ chromosome homologous to the autosomal gene for arginnosuccinate synthetase Nature $298 \quad 682-684$

34 Leroy, P, Seboun, E, Matte, M G , Fellous, M and Bishop, C E (1987) Testis spectic transcripts detected by a human Y-derived probe Development 101 (supp) $177-183$ 